\title{
Preliminary Insights on the Acehnese Daily Stressors in Conflict Affected Area
}

\author{
Fairuziana Humam Hamid \\ Community Mental Health Research Group, Faculty of Psychology, Universitas Indonesia \\ fairuziana@ui.ac.id \\ Gloryka Ednadita \\ Faculty of Psychology, Universitas Indonesia \\ ednadita.gloryka@ui.ac.id
}

\begin{abstract}
The 2005 peace memorandum was a significant event for the development of Aceh province, following 30 years living in the adversity of political conflict and violence. Persistent stress in post-conflict communities may occur due to daily life hardships related to economic and political instability, such as access to education, employment, and others. These stresses are referred to as daily stressors. The purpose of this study is to explore the preliminary insights of daily stressors among the Acehnese I 3 years following the peace memorandum. The study was conducted in the city center of North Aceh, one of the regencies that were highly affected by political conflict and violence. We recruited 20 participants with convenience sampling that were consisted of village headmen and local villagers from one of the villages in North Aceh. The study employed qualitative design by collecting data with focus group discussion and data were analyzed with thematic analysis. The study results discuss preliminary findings to provide meaningful knowledge related to daily stressors in conflict-affected areas in Aceh.
\end{abstract}

Keywords: Acehnese, daily stressors, political and violence conflict

Received 29 June 2019/Accepted 27 February 2020 @JEHCP All rights reserved

\section{Introduction}

A study by Good, Good, Grayman and Lakoma (2005) documented a high prevalence of mental health issues, anxiety and post-traumatic stress disorder among 596 Acehnese following the peace memorandum in Aceh. They found that $65 \%$ of the sample ranked high on depression symptoms, $69 \%$ of anxiety symptoms, and $34 \%$ on PTSD symptoms. According to the Indonesia Basic Health Research (Badan Penelitian dan Pengembangan Kesehatan, 20I8), 0.9\% or I out 100 persons in 
Aceh has psychosis, which most commonly is schizophrenia. In the Basic Health Research in 2007 and 2013, Aceh is ranked as the second highest prevalence for having persons with psychosis. In 2018, the rank improved to fourth place.

Seeing many health issues persist even after the conflict ended, it calls into question the present living conditions of the Acehnese. The 2005 peace memorandum was a major event for the development of Aceh province, following 30 years living in the conflict instability. After the peace treaty, the conflict left the government with a huge task to not only build the physical infrastructure but also to improve the social capital through economic growth, quality of education, health access, and justice engagement by implementing the truth and justice reconciliation (Asia Justice for Rights \& KontraS, 2017). According to the conflict intensity index that was conducted in 227 districts in Aceh, up to 54 districts were each highly and moderately exposed by post-conflict adversities (World Bank, 2008). The main regencies that were highly affected by the conflict by the order are East Aceh, Bireuen, North Aceh, Pidie, and South Aceh.

Post-conflict adversities mainly consist of financial difficulties and unemployment (Newnham, Pearson, Stein \& Betancourt, 2015).The three decades conflict between the Indonesian government and the separatist rebellion has increased the poverty rate in Aceh (World Bank, 2008). Throughout the peace-building process, Aceh was granted a special autonomy budget from 2008 until 2027 , on top of the annual state budget to mobilize the development lag. However, with the highest state budget in Indonesia does not immediately increased its economic growth. 13 years following the end of the conflict, Aceh's poverty rate is 15, $97 \%$ which is above the national rate of 9, 82\% (Mahdi, 2018). The disadvantaged population in Aceh had several characteristics as followings: larger household members, lower educational degree, woman as the breadwinner, and agriculture as thepe capital income. The unemployment number in Aceh is rated as the highest in Sumatra and ranked as one of the poorest provinces nationwide, and the first among other provinces in the island (IDeaS, 2017). While the generous aid has focused on the post-tsunami aid, few have come to aid areas faced with three decades' effect of the conflict (Waizenegger \& Hyndman, 2010). The inability to find a house and providing for a family are predictors of later psychological dysfunction (Newnham, et.al., 20I5). 
These adversities were found to impact the psychological well-being and individual functioning severely, including to increase the likelihood of developing post-traumatic stress disorder (Newnham et al., 20I5). In accordance, Fernando et.al. (2010), as well as Davidson, Hughes, Blazer and George (1991), found that greater job instability and lack of material resources were significantly correlated with post-traumatic stress disorder. Compared to the past traumatic experience, adverse situation after the conflict such as unemployment, financial difficulties and family separation can potentially predict anxiety and depression (Betancourt, et.al. 2010; Miller, et.al., 2008). Youth who missed the opportunity to develop education or employment skills during the war are more likely to carry high-level dysfunctional symptoms over time (Betancourt, Mc Bain, Newnham \& Brennan, 2013). Consistent to the previous study, Newnham, et al. (2015) found that exposure to economic and interpersonal stressors predicts young people's later psychological dysfunction.

Seeing its significant negative impact on mental health, it is important to assess these adversities. One of the ways to assess these adversities is to explore their daily stressors (Newnham, et. al., 2015). Daily stressor means persistently stressful conditions of daily life that are caused or exacerbated by armed conflicts such as poverty, family violence, social marginalization, impaired parenting due to parental distress, or lack of access to education (Miller et.al., 2009; Newnham et al., 20I5). Daily stressor in a post-war setting is related to the ongoing experience after the war ends and consisted of stressful material and social conditions. The stress might occur due to basic needs and basic security. According to Miller and Rasmussen (2009), some daily stressors might not occur on a daily basis as it also includes chronic low level stressors, such as overcrowded housing. The daily is emphasized on the fear of recurrence and vulnerability to such events.

Although faced with war adversities, some people might not develop nor maintain post-traumatic symptoms if not being aggravated by the daily stressors. Studies showed that there is a relationship between post-traumatic symptoms and war adversities mediated by the daily stressors (Fernando, Miller \& Berger, 2010; King, King, Fairbank, Keane \& Adams, 1998; Miller \& Rasmussen, 2010). Newnham, et.al., (2015) elaborated that individuals with severe experience during a war will have more issues in the psychological wellbeing due to economic and interpersonal issue after the war rather than the war exposure itself. More than direct war traumas, ongoing instability and hardship might contribute to poorer mental health outcomes. Studies on people affected by war are shifting 
focus from mental health issues resulted from direct trauma to the role of daily stressors which is worsened by the economic and political instability (Fernando, Miller \& Berger, 2010; Miller, et. al., 2010; Newnham, et. al., 20I5). Miller and Rasmussen (2009) found that putting greater attention to the daily stressors yielded more benefits to the improvement of mental health. It was revealed that daily stressors significantly enhanced the explanatory power for many mental health outcomes and psychiatric symptomatology.

One of the most widely used instruments for daily stressors is Afghan Daily Stressors Scale (ADSS) (Miller, Omidian, Rasmussen, Yaqubi \& Daudzai, 2008). This instrument consisted of 26 items regarding stressors in daily life faced for the last month. ADSS was developed using qualitative study with focus group discussion using factor analysis, which identified two subscales, which are socioeconomic stressors and family stressors. Several items include poverty, unemployment, security, housing problems, poor health, and others. Higher scores mean higher daily stressors experienced. This instrument had good internal consistency, construct and predictive validity with significant correlations with other tests such as Birleson Depression Self-Rating Scale and Marleson Anxiety Scale (Miller, Omidian, et al., 2006; Miller \& Rasmussen, 2009; Miller et al, 2009).

This is a preliminary study to explore the daily stressors among the Acehnese 13 years following the peace memorandum. Most studies of the Acehnese psychological stress have been highly concentrated on the 2004 Tsunami exposure (Agustini, 20II; Epping, et.al, 2015; Wiguna et.al, 2010; Du, Lee, Christina, Belfer, Betancourt, O'Rourke, \& Palfrey, J. S. 20I2), which happens right before the end of the political conflict. Consequently, the shifting attention has addressed the lack of study among the Acehnese who were affected by the political conflict after it ended. Among the 14 districts that were affected by the conflict, less than half were affected by the tsunami. Eventually, there has been a gap in development between the urban and rural area after the conflict and tsunami (Miller \& Bunnel, 2013). People living in areas directly affected by conflict shows a higher distress level than those who are indirectly exposed (Turnip, Klungsøyr \& Hauff, 20I0).

The purpose of this qualitative study is to describe the daily stressors, which is related to the wellbeing and functioning of people who were affected by war. As there are cultural variations in the understanding and expression of distress (Miller et al, 2009; Joop, de Jong, Komproe, \& Ommeren, $200 \mathrm{I})$, this study is needed to explore daily stressors while taking regard the life context of the 
Acehnese. We recruited 20 participants and conducted two focus group discussions. We used ADSS and interview guidelines formulated by Miller et al. (2009). The data were analyzed with thematic analysis. Studies in conflict-affected LMIC (Lower Middle-Income Countries) are local experiences which would contribute to the knowledge and development of mental health infrastructure (Tol, Rees \& Silove, 2013; Newnham, 2015).

\section{Method}

This is a preliminary qualitative study. We conducted a focus group discussion to gain insight on the local daily stressors and the content validity of the Afghan Daily Stressors Scale (ADSS) developed by Miller and Rasmussen (2009). Focus group discussion is an interview among a group of people who are familiar with a certain topic (Krueger\& Casey, 2008). According to Patton (2002), a focus group discussion would provide data from people's view on each other's perspective without the need to agree on each other. Studies revealed that focus group is a quick and efficient method to identify local daily stressors (Miller \& Rasmussen, 2009). According to the field notes, the findings are considered as a meaningful data since the result offers a rich description to the study purpose.

\section{Participants}

Focus group discussion commonly recruits participants with purposive sampling. In this preliminary study, the participants were recruited using convenience sampling due to the researcher's access to the study population in a sensitive setting. The participants consist of villages' headmen who is part of APDESI (Asosiasi Perangkat Desa Seluruh Indonesia) or the Village Stakeholder Association Nationwide of Indonesia, in North Aceh. In addition, the study also involved a group of villagers from one of the villages in North Aceh, AlueAnoeTimu. The inclusion criteria for the participants were: man and woman who had lived in the location of interest at least when they were above 18 years old and specifically were living in Aceh since 13 years ago or during the conflict until recent. Each group had 10 participants.

\section{Procedure}

The study was conducted in July 2018. The researcher was in contact with the villagers through a local organization, BYTRA, for assistance. The researcher informed regarding the study purpose and the criteria of potential participants. The local organization then provided contact with the 
village headmen network. The representative of the village headmen are those who were able to attend BYTRA office in the city centre of North Aceh.

In the beginning of the study, we provided an informed consent to the participants specifying our purpose, procedure, confidentiality, as well as participants' rights and protection. This form also contained a psychologist's contact information, should they feel the need to talk to a professional. We also provided verbal explanation and time for answering participants' questions. The focus group discussion was held shortly before the participants fill in the piloted study questionnaire. The head of the villages received no reward while the participants received a reward package with a value up to Rp.20,000.

A two-hour's focus group discussion was conducted with 10 villages' headman. At the end of the discussion, the village headmen were asked to provide feedback for the content validity of a different set of measurement scales for the same study. In the next day, one of the head villagers gave permission to visit his governing area in AlueAnoeTimu. A focus group discussion with a similar set of questions was delivered.

\section{Data Analysis}

The focus group discussion addressed several questions to explore the recent condition of the conflict-affected community in terms of social economic conditions and daily stressors. The questions are as follows: I. How is the recent condition of the Acehnese in the conflict-affected areas regarding their social economic condition? 2. How do you consider the post-war adversities regards to the community's daily stressor? Consistent with Miller, et al. (2009) as well as Bolton and Tang (2002), we also asked the participants to identify anything that made the young people's lives difficult and stressful in the setting where they lived. Moreover, we explore the relevance and experience of each of the ADSS' items to the participants.

The discussion was conducted fully in the Acehnese local language since the researcher speaks it fluently as her mother tongue. The data were analyzed with thematic content analysis. Content analysis is conducted by finding the recurring patterns of meaning in the field notes. The measurement observes the variety and frequency of a message. This technique is the basic 
qualitative data analysis, however, the practice is arguably quantitative in nature since it searches the number of speech pattern and phrase (Merriam \& Tisdell, 2009).

\section{Result}

The study result consists of main themes that are generated from the research findings. Since the focus group discussion topic was broad regarding the recent condition related to the post-war adversities and daily stressors, only some themes could be generated. Each of the themes is represented by both the villages' headman and the local villagers in AlueAnoeTimu, North Aceh. The word "daily stressor is described under the theme of "Meaning of Peace, "Lack of Trust", and "Youth related Issues". These findings are based on the field notes due to accidental damage to the digital recording.

\section{Meaning of Peace}

According to the discussion with the villages' stakeholders and villagers, the recent condition after the peace memorandum is related to the meaning of peace itself. According to a village headman, "We can feel at peace now because it's easier to go out during the night. In the past, this is not possible”. However, most of the participants question the meaning of peace, regards to the long term impact that remains until recently. A village headman said "The impact of the war has not been fully recovered yet. This is related to the political and economic policy that has not taken its' side for the common people".

After the political conflict and violence ended, the government was committed to providing some sort of aid for the "victims" to rebuild the houses. However, according to a village headman, the term "victim" is vague. A victim could be the former combatant, the child of a family of the combatants, or a common people. This unclear definition turns out to become a mismatch issue in identifying persons or family who are really in need of the government's aid. According to the field notes, most participants feel that the recovery after peace is related to the aid that they receive as victims. If the aid is not equally distributed, then there is a sense that justice is not equally distributed, which makes them question the meaning of peace. A village headman said that people are looking for the "Justice Queen” because is in this opinion, there is no concept for Aceh's post- 
conflict development. This term was used to define the poverty situation in the community and people feel they have nowhere to go about it.

\section{Lack of Trust}

Lack of trust to the government became the main topic that was mentioned a couple of times by both the village headman and the villagers. They expressed the lack of trust in the provincial government. Besides the aid house, the lack of public infrastructure, such as paved-road become one of the most discussed issue to become a source of stress and problem among the community. The lack of paved-road in remote villages gives an impact for access, including to reach health and education facilities. It is common for the students in the village to skip school when they have no vehicle to take them to school, or would basically drop out of school because their parents cannot afford to have a motorbike.

A headman village added that the social gap is increasing between the communities. After the peace of memorandum, the village headman admits that the villagers have more courage in a way that they could beat other people easier. It was unclear why people beat on each other. One of the headmen said, "People have no more direction". There is no clear description regarding the social engagement among the community or in the domestic areas to relate the issues with family stressors or violence.

\section{Youth related Issues}

Education also received attention among young people. A village headman said that "In the young people's perspective, you don't need to be so smart to become a leader. The leader that we have now are not those who are educated, but they are people with a loud voice and "wide-bold-eyes". This becomes an issue among the village headman since it has been quite difficult to show the advantages of education to young people when there is no good role model.

Drug abuse becomes the next main issue that was discussed among the villagers. The community are aware that narcotics are more accessible in the village, which is a real threat to the community. Parents are also concern regarding drugs that might threaten their child. One of the most worrying 
concerns is related to the accessible use of narcotics in remote areas in Aceh that inadvertently triggers the youth's curiosity to experiment with the narcotics.

Both the headman the villagers are concern regarding the access for internet in each of the village. They are concern related to technology abuse with the Wi-Fi facility in the village. Each of the villages in North Aceh is recently receiving access to have a public Wi-Fi in the village. Some headman village opposes this technological upgrading since they observed that the youth are only wasting their time with their smartphones when connected to the internet. Some villages keep the Wi Fl access in the area but also received complaints from parents who are cautious about their children's time consumption in using internet, access to dangerous content, and the ability to afford the smartphone itself. As most of the villagers have low education, they are not in the capacity to educate young people regarding the good and bad use of technology.

Lastly, the concern of many villagers is related to access for employment. The main occupation around the villages is farming, planting, sea fishing, and fish farming. The village headman claimed that the access for employment is basically difficult. However, there is a common knowledge that the former combatants or persons related to the former freedom movement have easier access for employment.

\section{Discussion}

According to the field experience, it looks and sounds at ease for the villagers to talk about the past conflict and violence, with the assumption that it was a collective experience or something that happened in the past to everyone in the area. Moreover, the headman village allowed the researcher to have the conversation related to the violence or torture that happened to the community, with the assumption that it is a common topic to be discussed. The conflict experience is still traumatic for some people, but they can deliver it as a common conversation. In comparison, having the conversation related to the current situation with the lack of opportunities for employment, education, and access for economy appears more stressful for the community. This situation was unexpected since the political conflict and violence has a major impression for the researcher to impact the community's emotions and mental state, compared to the current 
situation. The researcher observes this as a hopeless and sorrow feeling from the villagers since the conflict has ended for more than 10 years, yet their life situation is not making significant progress.

During the group discussion, the term daily stressor or "stress" is rarely used in the conversation since this term means differently among the population. The terms they used were mostly physical and emotional manifestations of stress such as "headache" and "worry", and so on. "Stress" in the Acehnese local language means having a mental illness. However, the villagers and village headman could grasp the meaning of stress in the general Indonesian language term. The findings in the result section are the reasons and backgrounds that the villagers understand and view as their source of stress, especially regarding the situation after the political conflict and violence have ended. The term stress is not used to explain individual stress, but more of a collective stress in the community.

Compared to ADSS, there are several similarities and differences with the local daily stressors of the Acehnese. Similarities include poverty, unemployment and poor education. According to Mahdi (2018), I out of 5 persons in Aceh is unemployed or poor workers, meaning their job cannot afford their daily needs. In the same study, the disadvantaged population in Aceh is revealed to have low educational degree. This is in line with previous studies such as Good et al. (2007), Miller and Rasmussen (2009), Miller et al., (2009) and Tol, Rees, Silove, et al. (20I3) in other conflict-affected countries.

Some of the daily stressors in the ADSS' items are perceived as not stressful, such as having biological children and too many children. The Acehnese did not perceived this as a source of stress since this was a gift from God. However, there are additional stressors that uniquely occur among Acehnese, which are lack of paved road, drug abuse, and unemployment. The lack of paved road affects the access to remote areas that inevitably becomes a barrier to reach the town. Due to many of the villagers have no motorbike and vehicle, they feel increasingly isolated. According to the Mundzir (2018), drug abuse is the rising and urgent problem among Acehnese, as also reported by several newspapers (Masriadi, 2019). He explained that social environmental factors, such as drug abuse might cause severe mental health problems and psychosis. Furthermore, in the same study, a survey conducted by Forum Bangun Aceh clarifies that unemployment is a source of stress for persons who had mental illness that may trigger a relapse. The results are relevant to previous 
findings that daily stressors are subject to context, so that different countries may reveal different stressors (Miller \& Rasmussen, 2009; Tol, Rees, Silove, et al, 20I3).

Consistent with previous studies on other conflict-affected regions (Miller \& Rasmussen, 2009; Miller et al., 2009; Newnham, et al., 20I5), the Acehnese also perceived that their daily stressors have a significant impact on their mental health and functioning, might even more than their direct war trauma experience. It could be explained by several reasons (Miller \& Rasmussen, 2009). First, the daily stressors might accumulate and persist in their everyday life for a long period of time. According to Sapolsky (2004), continuous lower level non-traumatic stressors gradually diminish physical and psychological health while also increasing vulnerability to illness. Thus, daily stressors more robustly predict distress than exposure to major life events. Second, daily stressors represent immediate and close stressors, whereas war exposure happened in the distant past. Thus, the existence of daily stressors is more apparent and salient to the locals. Third, not all the locals have experienced the war directly nor with the same intensity, while daily stressors are more undiscriminating and pervasive (Miller et al., 2009). Lastly, daily stressors refer to the stressful circumstances that may increase feelings of lack of control. Feelings of lack of control over the basic resources may significantly contribute to the perception of those events as stressful (Sapolsky, 2004).

This study has meaningful implications on the knowledge and development of mental health infrastructure in conflict-affected areas in Aceh. According to the previous studies (Fernando et al., 200 I; King, King, Fairbank, Keane \& Adams, 1998; Miller \& Rasmussen, 2010; Newnham, et al., 20I5), daily stressor is a more robust predictor than war-related trauma on many mental health outcomes and psychiatric symptomatology. Thus, it is of high importance to address these stressors and allocate the needed basic resources to improve the Acehnese' mental health. The government, related stakeholders and authorities should not just focus on providing clinical service to the Acehnese but also target these stressors.

This study has several limitations. First, the daily stressors are identified in a specific context and culture. Thus, it limits the generalizability of the results to other contexts, where other daily stressors might be more pervasive. Second, the recording of the group discussion was accidentally damaged. Thus, we regrettably were unable to provide the complete verbatim. However, the 
comprehensive field notes was quite sufficient to conduct the analysis. Third, due to technical difficulties and low accessibility to the sample, we only managed to recruit 20 participants conveniently. This small sample size may contribute to some bias of the findings.

\section{Conclusion}

According to the current situation, the Acehnese elaborates daily stressors related to the meaning of peace, lack of trust, and several youth related issues such as internet abuse, drug abuse, poor education, and unemployment. The Acehnese perceived these daily stressors as detrimental to their mental health. Therefore, these factors are important to consider to improve the mental health and well-being, even long after the conflict has ended. This study contributes to the understanding of the social and psychological problems in a community affected by conflict for a long time.

Several suggestions for future studies are as follows. Regards to the study scope, future research could consider to research the community's sense to violence and actual violence in the present. Most studies found that youth living in a post conflict setting have been exposed to some kind of violence in their community (Das-Munshi et al., 2017; Fausiah, Turnip, \& Hauff, 2019; Kaminer, du Plessis, Hardy, \& Benjamin, 2013; McAloney, McCrystal, Percy, \& McCartan, 2009). The fact the community discussed political violence in an ease manner might be a sign of the increasing sense to tolerate violence.

For the method some of the recommendations are firstly, researchers may employ mixed design where they conduct a qualitative study to explore the daily stressors and quantitative study to assess its psychometric properties. Secondly, future qualitative study may benefit from using a more structured interview to gain insight on specific daily stressors and their impact to particular mental health issues. Thirdly, researchers may increase the size and representativeness of the sample. Lastly, longitudinal study can be conducted to see the changes in the daily stressors faced by the Acehnese over the years. 


\section{Acknowledgement}

This research funding was supported by a research grant in the Faculty of Psychology, Universitas Indonesia in 2018. We would like to thank BYTRA for the local assistance to engage with the participants. We are also delighted for the representatives of APDESI (Asosiasi Perangkat Desa seIndonesia) in North Aceh who provided their insights as stakeholders, although they may not agree with all of the interpretations/conclusions of this paper.

\section{References}

Agustini, E. N., Asniar, I., \& Matsuo, H. (20II). The prevalence of long-term post-traumatic stress symptoms among adolescents after the tsunami in Aceh. Journal of psychiatric and mental health nursing, 18(6), 543-549.

Asia Justice for Rights (AJAR) \&KontraS. (2017). SatuTahunKomisiKebenarandanRekonsiliasi Aceh (KKRA): PengungkapanKebenaranatasPeristiwaPelanggaran HAM di Aceh sebagaiUpayaMemperkuatPerdamaian. Press Release retrieved from http://asiaajar.org/2017/I I/press-release-first-year-anni versary-aceh-tr.

Badan Penelitian danPengembanganKesehatan. (2018). RisetKesehatanDasar. KementerianKesehatan RI. Jakarta

Betancourt, T. S., Borisova, I. I., Williams, T. P., Brennan, R. T., Whitfield, T. H., De La Soudiere, M., ...\& Gilman, S. E. (2010). Sierra Leone's former child soldiers: A follow-up study of psychosocial adjustment and community reintegration. Child development, 8I (4), doi:I077-I095.

Betancourt, T. S., McBain, R., Newnham, E. A., \& Brennan, R. T. (20I3). Trajectories of Internalizing Problems in War-Affected Sierra Leonean Youth:Examining Conflict and Post conflict Factors. Child Development, 84(2), 455-470. http://doi.org/I0.I I I I/j. I467-8624.20I2.0186 I

Betancourt, T. S.; Newnham, Elizabeth A.; Hann, Katrina; McBain, Ryan K.; Akinsulure-Smith, Adeyinka M.; Weisz, John; Lilienthal, Grace M.; and Hansen, Nathan. (20I4). Addressing the Consequences of Violence and Adversity: The Development of a Group Mental Health Intervention for War-Affected Youth in Sierra Leone". CUNY Academic Works. Retrieved from http://academicworks.cuny.edu/cc_pubs/387.

Bolton, P., \& Tang, A. M. (2002). An alternative approach to cross-cultural function assessment. Social psychiatry and psychiatric epidemiology, 37(I I), 537-543.

Das-Munshi, J., Mathews, C., Adams, A., Stansfeld, S. A., Clark, C., Lund, C., \&Rothon, C. (2017). Exposure to violence and mental health of adolescents: South African Health and Well-being Study. BJPsych Open, 3(05), 257-264. http://doi.org/ I 0.I I 92/bjpo.bp.I I 7.00486 I

Davidson, J., Hughes, D., Blazer, D., \& George, L. (199I). Post-traumatic stress disorder in the community: An epidemiological study. Psychological Medicine, 2 I (3), 7I3-72I. doi:I0.1017/S0033291700022352

Du, Y. B., Lee, C. T., Christina, D., Belfer, M. L., Betancourt, T. S., O'Rourke, E. J., \& Palfrey, J. S. (2012). The living environment and children's fears following the Indonesian tsunami. Disasters, 36(3), 495-5I3.

Epping-Jordan, J. E., Van Ommeren, M., Ashour, H. N., Maramis, A., Marini, A., Mohanraj, A., ...\&Suveendran, T. (20I5). Beyond the crisis: building back better mental health care in 10 
emergency-affected areas using a longer-term perspective. International journal of mental health systems, 9(I), I5.

Fausiah, F., Turnip, S. S., \&Hauff, E. (2019). Community violence exposure and determinants of adolescent mental health: A school-based study of a post-conflict area in Indonesia. Asian Journal of Psychiatry, 40(September 2018), 49-54. http://doi.org/10.1016/j.ajp.2019.01.020

Fernando, G. A., Miller, K. E., \& Berger, D. E. (2010). Growing pains: The impact of disaster-related and daily stressors on the psychological and psychosocial functioning of youth in Sri Lanka. Child development, 8I (4), II92-I2I0.

Good, M. J., Good, B. J., Grayman, J. H., \&Lakoma, M. (2007). A psychosocial needs assessment of communities in 14 conflict-affected districts in Aceh. International Organization for Migration. Retrieved from http://hdl.handle.net/2292/2674I

IDeAs, Institute for Development of Aceh Society. (2017). IDeASIngatkan Tingkat Kemiskinan Aceh MasihTertinggi di Sumatera Article retrieved from https://www.acehtrend.com/2017/07/I7/ideas-ingatkan-tingkat-kemiskinan-aceh- masihtertinggi-di-sumatera/

Joop, T. V. M., de Jong, M.D., Komproe, I. H., Ommeren, M. V., Masri, M. E., Araya, M., Khaled, N., de Put, W. N., Somasundaram, D. (200I). Lifetime events and post traumatic disorder in 4 post-conflict settings. JAMA, 286(5), 555-562. https://doi.org//0.100 I/jama.286.5.555

Kaminer, D., du Plessis, B., Hardy, A., \& Benjamin, A. (2013). Exposure to violence across multiple sites among young South African adolescents. Peace and Conflict, 19(2), II2124.http://doi.org// 0.1037/a0032487

King, L. A., King, D. W., Fairbank, J. A., Keane, T. M., \& Adams, G. A. (1998). Resilience-recovery factors in post-traumatic stress disorder among female and male Vietnam veterans: Hardiness, postwar social support, and additional stressful life events. Journal of Personality and Social Psychology, 74(2), 420-434. https://doi.org/I0.1037//0022-35I4.74.2.420

Krueger, R. A. \& Casey, M.A. (2008). Focus groups: A practical guide for applied research. $4^{\text {th }}$ Edition Sage publications.

Masriadi. (2019). PolisiDitembaki Bandar Narkoba di Aceh Utara. Retrieved from https://regional.kompas.com/read/2019/0 I/I I//547487I/polisi-ditembaki-bandar-narkoba-diaceh-utara

McAloney, K., McCrystal, P., Percy, A., \& McCartan, C. (2009). Damaged Youth: Prevalence of community violence exposure and implications for adolescent well-being in post-conflict Northern Ireland. Journal of Community Psychology, 37(I), 88-105. http://doi.org/I0.1002/jcop

Merriam, S. B., \&Tisdell, E. J. (2009). Qualitative data analysis. Qualitative research: A guide to design and implementation, 169-207.

Miller, K. E., Omidian, P., Rasmussen, A., Yaqubi, A., \&Daudzai, H. (2008). Daily stressors, war experiences, and mental health in Afghanistan. Transcultural Psychiatry, 45(4), 6I I-638.

Miller, K. E., Fernando, G. A., \& Berger, D. E. (2009). Daily stressors in the lives of Sri Lankan youth: a mixed methods approach to assessment in a context of war and natural disaster. Intervention, 7(3), I87-203. https://doi.org/10.1097/wtf. 0b0 I3e3283346344

Miller, K. E., \& Rasmussen, A. (2010). War exposure, daily stressors, and mental health in conflict and post- conflict settings: bridging the divide between trauma- focused and psychosocial

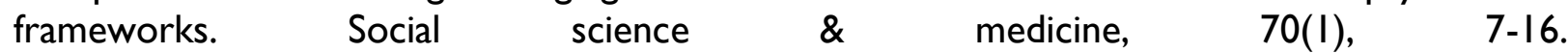
https://doi.org/10.1016/j.socscimed.2009.09.029

Miller, K. E., \& Rasmussen, A. (20I4). War experiences, daily stressors and mental health five years on: elaborations and future directions. Intervention, 12, 33- 42. https://doi.org// 0.1097/wtf.0000000000000066 
Miller, K. E., Omidian, P., Rasmussen, A., Yaqubi, A., and Daudzai, H. (20I4). Daily stressors, war experiences, and mental health in Afghanistan. Transcultural Psychiatry, 45(4), 6II-638. https://doi.org/10.1/77//36346/508/00785

Mahdi, S. (2018). Muda, Menganggur, Miskin: AspekDemogafidanSosialEkonomiKekerasanPascaKonflik Aceh in CatatanAkhirTahun 2018 Poros Darussalam. Aceh. Retrieved from http://www.acehkita.com/wp-content/uploads/2019/ 0l/Catatan-Akhir-Tahun-Poros-Darussalam.pdf

Mundzir, I. (2018). Kesehatanjiwa Aceh 2018: Lebih Baik dariRerata Nasional, tapi tidak untuk GangguanjiwaBerat, in CatatanAkhirTahun 2018 Poros Darussalam. Aceh. Retrieved from http://www.acehkita.com/wp-content/uploads/2019/ 0I/Catatan-Akhir-Tahun-PorosDarussalam.pdf

Newnham, E. A., McBain, R. K., Hann, K.,Akinsulure-Smith, A. M., Weisz, J., Lilienthal, G. M., ... \& Betancourt, T. S. (2015). The Youth Readiness Intervention for war-affected youth. Journal of Adolescent Health, 56(6), 606-6II. https://doi.org/10.1016/j.jadohealth.2015.01.020

Newnham, E. A., Pearson, R. M., Stein, A., \& Betancourt, T. S. (2015). Youth mental health after civil war: the importance of daily stressors. The British Journal of Psychiatry, 206(2), II6-121. https://doi.org/10.1 192/bjp.bp.II4.146324

Neill, M. O., Reichman, W., Klobas, J., Maclachlan, M., Hui, H. C., \&Carr, S. C. (20II). Humanitarian work psychology: The contributions of organizational psychology to poverty reduction. Journal of Economic Psychology, 32(2), 240-247. https://doi.org/10.1016/j.joep.2009.10.009

Patton, M. Q. (2002). Qualitative research and evaluation methods. Thousand Oaks. Cal.: Sage Publications.

Sapolsky, R. (2004). Why zebras don't get ulcers. New York: Owl Books.

Tol, W. A., Rees, S. J., \&Silove, D. M. (2013). Broadening the scope of epidemiology in conflictaffected settings: opportunities for mental health prevention and promotion. Epidemiology and Psychiatric Sciences, 22(3), 197-203. https://doi.org/I0.1017/s20457960I3000I 88

Tol, W. A., Reis, R., Susanty, D., \& de Jong, J. T. (2010). Communal violence and child psychosocial well-being: qualitative findings from Poso, Indonesia. Transcultural Psychiatry, 47(I), II2-I35. https://doi.org/I0.II77/I363461510364573.

Turnip, S. S., Klungsøyr, O., \&Hauff, E. (2010). The mental health of populations directly and indirectly exposed to violent conflict in Indonesia. Conflict and health, 4(I), I4. https://doi.org/10.1186/1752-1505-4-14.

Waizenegger, A., \& Hyndman, J. (2010). Two solitudes: post-tsunami and post-conflict Aceh. Disasters, 34(3), 787-808. https://doi.org/I0.1III/j.1467-77/7.2010.01I69.x

Wiguna, T., Guerrero, A. P., Kaligis, F., \&Khamelia, M. (2010). Psychiatric morbidity among children in North Aceh district (Indonesia) exposed to the 26 December 2004 tsunami. Asia-Pacific Psychiatry, 2(3), I5I-I55.

World Bank (2008). Dampakkonflik, tsunami, danrekonstruksiterhadapkemiskinan di Aceh, KajianKemiskinan di Aceh tahun 2008. Retrieved from http://siteresources.worldbank.org/INTINDONESIA/Resources/Publication/2800 I61200376036925/acehpoverty2008_bh.pdf 